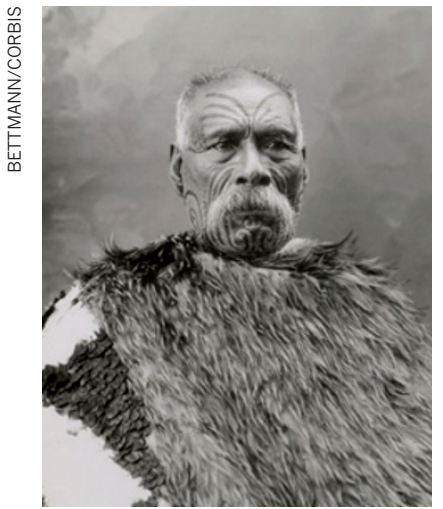

ANTHROPOLOGY

\section{Kiwi DNA tells Maori history}

The Maori people of New

Zealand cherish their kiwi feather cloaks (pictured). An analysis of DNA extracted from the feathers offers clues to the garments' early history.

David Lambert at Griffith University in Nathan,

Australia, and his team sequenced the DNA of kiwi feather samples from 109 cloaks held in museums in New Zealand and the United Kingdom. They compared the sequences to those from kiwis living in 26 locations on $\mathrm{New}$ Zealand's North Island.

Most of the feathers came from the North Island brown kiwi (Apteryx mantelli). However, $15 \%$ of the cloaks held feathers from populations in different areas, hinting at the existence of a feather trade. More than one-third of the garments included feathers from birds restricted to an eastern pocket of the North Island, which could be where cloak-making traditions started, the authors say. Mol. Biol. Evol. doi:10.1093/ molbev/msr107 (2011)

For a longer story on this research, see go.nature.com/ kwybla

\section{PHYSICS}

\section{Location counts in search for waves}

Massive objects such as orbiting neutron stars can bend the Universe's flexible space-time fabric, generating gravitational waves. Four wave detectors are expected to be operational on Earth by 2016 . However, having an additional detector in the right place could double or even quadruple the expected detection rate, says Bernard Schutz at the Albert Einstein Institute in Potsdam, Germany.

He calculated changes in detection rate, sky coverage and directional accuracy of the network when three or more detectors are placed around the world. He found that moving one of the three detectors currently planned for the United States to Australia and adding a detector in Japan (which is now being funded) would nearly double the sky coverage. In addition, it would lower the error rate in measuring the angular position of events sixfold.

Classical Quant. Grav.

doi:10.1088/0264-

9381/28/12/125023 (2011)

\section{ANIMAL BEHAVIOUR}

\section{Turtle embryos seek sunny side}

Just as adult turtles warm themselves in the midday Sun, turtle embryos 'bask' in their eggs by cosying up to the Sunwarmed side.

Wei-Guo Du at the Chinese Academy of Sciences in Beijing and his colleagues shone light through the freshly laid eggs of softshell turtles (Pelodiscus sinensis) to mark the positions of the embryos inside. The team then incubated the eggs, warming them either from above or from one side. Over a period of days, embryos made

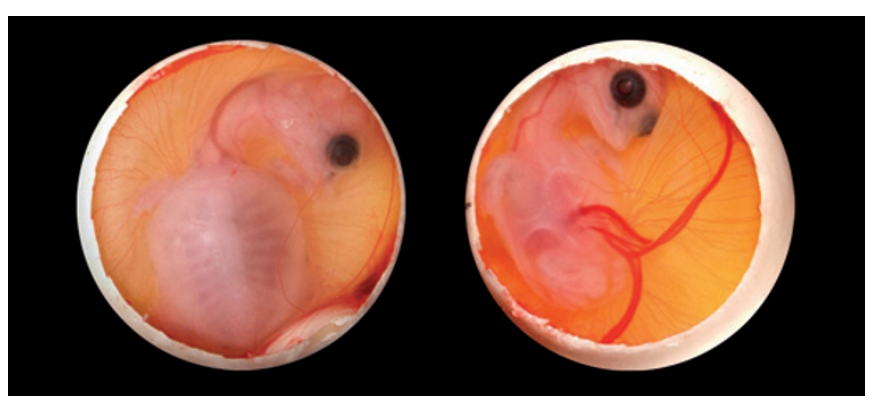

spore-like stages, which are shed in cat faeces. The three main strains of T. gondii vary widely in terms of virulence in mice, and researchers have pinpointed a gene that may underlie this difference.

David Sibley at Washington University in St Louis, Missouri, and his co-workers generated a genetic cross between the type I strain, which is lethal to lab mice, and the milder type II. The progeny were injected into mice to assess their virulence. A genome-wide association analysis of the progeny and the parental strains revealed a locus on chromosome XII that accounted for $90 \%$ of the heightened virulence. Deleting a gene within this region, $R O P 5$, in the type I strain completely blocked acute virulence.

The authors suggest that the ROP5 protein may regulate other proteins that control virulence in the parasite. Proc. Natl Acad. Sci. USA doi:10.1073/pnas.1015338108 (2011)

\section{$\rightarrow$ NATURE.COM}

For the latest research published by Naturevisit:

www.nature,com/latestresearch 